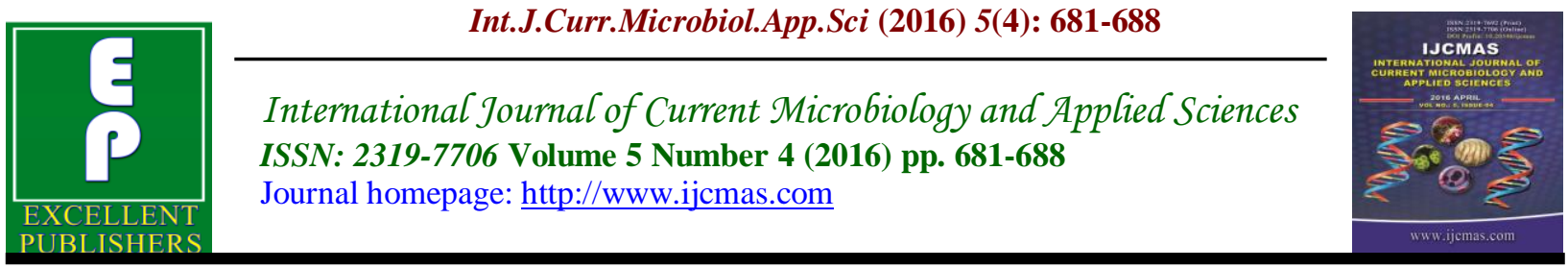

Original Research Article

http://dx.doi.org/10.20546/ijcmas.2016.504.078

\title{
Antibacterial Activity of Herbal Plants
}

\author{
P. Akila, L. Prince*, R. Bharathidasan and K. Krishnapriya \\ PG \& Research Department of Microbiology, Marudupandiyar college, Vallam-613,403, \\ Thanjavur-District, TamilNadu, India \\ *Corresponding author
}

\begin{tabular}{|c|c|}
\hline & A B S T R A C T \\
\hline Keywords & The main objective of the study was to find the antibacterial activity of plant \\
\hline $\begin{array}{l}\text { Traditional } \\
\text { medicine, } \\
\text { Antibacterial } \\
\text { activity, } \\
\text { Herbal } \\
\text { plants. }\end{array}$ & $\begin{array}{l}\text { Adhatoda vasica, Aegle marmelos, Aristolochia bracteolata, } \\
\text { Cardiospermum halicacabum, Cordia myxa, Eclipta alba, Mukia } \\
\text { maderaspatuna, Ocimum basilicum, Plectranthus ambionicus and Solanum } \\
\text { xanthocarpum. The antibacterial activity was determined by the agar well } \\
\text { diffusion method. The antibacterial activity was against three gram positive } \\
\text { bacteria Bacillus subtilis, Streptococcus pyogenes, Staphylcoccus aureus }\end{array}$ \\
\hline Article Info & and two gram negative bacterial strains Pseudomonas aeruginosa and \\
\hline $\begin{array}{l}\text { Accepted: } \\
22 \text { March } 2016 \\
\text { Available Online: } \\
10 \text { April } 2016\end{array}$ & $\begin{array}{l}\text { Ethanol extract. For the present study these one plant were screened to } \\
\text { detect the presence of the active metabolites like saponins, tannins and } \\
\text { terpenoids. }\end{array}$ \\
\hline
\end{tabular}

\section{Introduction}

The plant Coleus ambionicus (synonym: Plectranthus ambionicus, Coleus aromaticus) commonly known as country borage, Indian borage, is a dicotyledonous plant belonging to the family Lamiaceae (Warrier, 1994). It is a large succulent aromatic parennial herb. Much branched, fleshy highly aromatic pubescent herb with distinctive smelling leaves. The plant is distributed throughout India, cultivated in the gardens. It is folkloric medicinal plant used to treat malarial fever, hepatopathy, renal and vesical calculi, cough, chronic asthma, (Nadkarni, 1996), hiccough, bronchitis, helminthiasis, colic and covulsions and epilepsy(Gil -otaiza, 1997). It is used to treat colds and cough as well as arthritic inflammations. Indian Material medica includes about 200 drugs of natural origin almost all of which are derived from different traditional system and folklore practices (Narayana et al., 1998). Antimicrobial activity of plants can be dedicated by observing the growth response of various microorganisms to those plant tissues or extracts, which are placed in them. Many methods for detecting such activity are available, but since they are not equally sensitive or even based on the same 
principle, the results obtained will also be influenced by the method selected and the microorganisms used for the test.

Henna (Lawsonia inermis L.) is a small shrub. Frequently cultivated in India, Persia, and along the the African coast of the Mediterranean sea. Powdered leaves of this plant, in the form of a paste, are used both has a cosmetic and as a remedy for boils, wounds and some my cotic infections in certain countries of the middle east (Krithiga and Jayachitra, 2012). Allopathic treatment may either be permanent or temporary depending on the patient's health has improved through nutritional methods, sometimes they can be weaned from the syunthetic drugs (Biswas 2006). Evaluation of indian traditional medicine is possible through the proper exploiration of wide biodiversity and great ancient treatises of traditional medicine with the light of modern tools and techniques (Mukherjee, 2002). Numerous medicinal plants and their formulation are used for disorders in the ethno medicines in India.

\section{Materials and Methods}

\section{Collection of Plant Sample}

Totally ten wound samples were collected from the government hospital outpatient at orathanadu. Samples were collected in a sterile screw cap test tubes. It was taken to the laboratory for the identification of pathogen. In case of delay the samples are kept in refrigerator in order to avoid multiplication of the normal flora.

\section{Screening the Organisms Present in the Wound Sample}

\section{Isolation and Identification of Wound Sample}

A loopful of wound sample collected from ten different outpatients were taken separately. It was streaked on the selective media such as Blood agar, Nutrient agar, Eosin methylene blue agar, MacConkey agar and Cetrimide agar and incubated at $37^{\circ} \mathrm{c}$ in aseptic condition for 24 hours. After the incubation period the individual colony emerging from the medium was sub cultured separately in the same medium for identification. They are identified morphologically and biochemical methods.

\section{Collection of Plant Sample}

Fresh plants were collected randomly from Marudupandiyar college herbal garden Thanjavur of Tamilnadu, India, in January 2016. The taxonomic identifies of this plant were determined by Dr.A. Panneerselvam, Department of botany and microbiology, associate professor A.V.V.M. Sri Pushpam college, poondi Thanjavur. Fresh plant materials were washed under running tap water, air dried and then homogenized to fine powder and stored in airtight bottles.

\section{Preparation of Plant Extract}

\section{Aqueous Extraction}

The aqueous extractions of the water soluble ingredients were carried out using the method as described by Azusu (1986). 15g of each of the grounded leaves were extracted by successive soaking for 2 days using $35 \mathrm{ml}$ of distilled water in a $250 \mathrm{ml}$ sterile conical flask. The extracts were filtered by using Whatman filter paper No.1.The filtrates were concentrated in vacuum at $60^{\circ} \mathrm{c}$ and stored in universal bottles and refrigerated at $4^{0} \mathrm{c}$ prior to use.

\section{Ethanol Extraction}

The ethanol extractions of the active ingredient of the leaves were prepared 25 pi of the herbal plants leaves were soxlet extracted using $250 \mathrm{ml}$ of $95 \%$ ethanol. The 
extraction lasted for six hours. The volatile oil obtained was concentrated by evaporation using water bath at $100^{\circ} \mathrm{c}$.

\section{Acetone Extraction}

The acetone extract was prepared by suspending $100 \mathrm{~g}$ of powdered leaves in $500 \mathrm{ml} 95 \%$ acetone. This mixture was diluted with $600 \mathrm{ml}$ of acetone and then allowed to stand for $24 \mathrm{hrs}$. The resulting extract was decanted and filtered through a whatman filter paper. The filtrate was the concentrated with rotary evaporator at $4^{0} \mathrm{c}$.

\section{Screening of Phytochemical Compounds}

The various solvent extracts of the coarse powder of leaves of herbal plants were subjected to phytochemical tests for the identification of various active constituents, using the methodology followed(Malcon and Sofowora, 1969). The following major pharmaceutically valuable phytochemical compounds were analyzed.

\section{Detection Saponin}

To one $\mathrm{ml}$ each of the various extracts were separately mixed with $20 \mathrm{ml}$ of distilled water and then agitated in a graduated cylinder for $15 \mathrm{~min}$. The formation of foam indicated the presence of saponins.

\section{Detection of Terpenoids}

To five $\mathrm{ml}$ each of various extracts were dissolved in $5 \mathrm{ml}$ of chloroform separately (stock solution). Then they were subjected to Libermann-Burchard test. To one $\mathrm{ml}$ of each of the stock solution, a few drops of acetic anhydride and $1 \mathrm{ml}$ of concentrated sulphuric acid were added from the sides of the test tubes and allowed to stand for $5 \mathrm{~min}$. Formation of brown ring at the junction of two layers and the upper layer turned green indicated the presence of terpenoids.

\section{Detection of Tannins}

To five $\mathrm{ml}$ each of the various extracts were dissolved in minimum amount of water separately and filtered. Then filtrates were taken separately and added a few drops of aqueous basic lead acetate solution. Formation of reddish brown colour precipitate indicated the presence of tannins.

\section{Test Organism}

Test bacterial strain was grown in nutrient broth for $18-24$ hours at $37^{\circ} \mathrm{c}$ on rotary shaker. Cells were kept at $4^{0} \mathrm{c}$.

\section{Antibacterial Susceptibility Testing}

Antibacterial activity of agar well diffusion method:

In the agar well diffusion inhibition test as described by Opara and Ansa, 1993,0.2ml of a $24 \mathrm{hr}$ broth culture of the bacteria was aseptically introduced and evenly spread using bent. Sterile glass rod on the surface of gelled sterile Muller-Hinton agar plates. Three wells about $6.0 \mathrm{~mm}$ diameter were aseptically punched on agar -plate using a sterile cork bore allowing at least $30 \mathrm{~mm}$ between adjacent wells and between peripheral wells and the edge of the petridish. Fixed volumes $(0.2 \mathrm{ml})$ of the leave extract were then introduced into the wells in the plates. A control well was in the centre with $0.01 \mathrm{ml}$ of the extracting solvent. The plates incubated at $37^{\circ} \mathrm{c}$ for $24 \mathrm{hr}$ for the test bacteria. The plates were duplicated in all the experiments.

\section{Results and Discussion}

The isolated organisms like Staphyloccocus aureus, Bacillus subtilis, Streptococcus pyogenes, Pseudomonas aeruginosa, Klebsiella pneumoniae exhibited the antibacterial activity for three solvents 
extracts acetone, aqueous and ethanol of herbal plants

\section{Acetone Extract}

Acetone extract of Adhatoda vasica, Solanum xanthocarpum, Plectranthus ambionicus, Cordia myxa, Cardiospermum halicacabum, Ocimum basilicum, Eclipta alba, Mukia maderaspatuna showed highest activity $15 \mathrm{~mm}, 12.5 \mathrm{~mm}, 12 \mathrm{~mm}$ against Staphylococcus aureus, Streptococcus pyogenes, Bacillus subtilis, Klebsiella pneumoniae and Pseudomonas aeruginosa.

\section{Ethanol Extract}

The ethanol extract of Plectranthus ambionicus, Solanum xanthocarpum, Cardiospermum halicacabum, Mukia maderaspatuna, Adhatoda vasica, Aristolochia bracteolata, Ocimum basilicum and Eclipta alba Showed maximum highest activity $\quad 17.5 \mathrm{~mm}, 15 \mathrm{~mm}, 14 \mathrm{~mm}, 12.5 \mathrm{~mm}$ against Staphylococcus aureus, Streptococcus pyogenes, Bacillus subtlis, Pseudomonas aeruginosa and Klebsiella pneumoniae.

\section{Aqueous Extract}

The aqueous extract of Aegle marmelos, Cordia myxa, Eclipta alba,Cardiospermum halicacabum, Solanum xanthocarpum, Plectranthus amboinicus maximum activity $12.5 \mathrm{~mm}, 12 \mathrm{~mm}, 10 \mathrm{~mm}$ and $9 \mathrm{~mm}$ against Streptocoocus pyogenes, Pseudomonas aeruginosa, Klebsiella pneumoniae and Staphylococcus aureus. The least activity $5 \mathrm{~mm}$ and $3 \mathrm{~mm}$ against Bacillus subtilis.

The antibacterial activity of selected ten plants ethanol, acetone and aqueous extracts was teste against the commonly acquired clinical pathogen of Bacillus subtilis,
Klebsiella pneumoniae, Pseudomonas aeruginosa, Staphylococcus aureus and Streptococcus pyogenes. The sensitivity test is done to determine the degree of sensitivity or resistance of the selected gram positive and gram negative pathogens toward the antimicrobial drugs.

Pseudomonas aeruginosa has shown the maximum zone of inhibition of $17.5 \mathrm{~mm}$ at the highest concentration of $200 \mu \mathrm{l}$, which proves that P.aeruginosa is susceptible toward the ethanolic extract of Adhatoda vasica which is significant to the research conducted by (Prasannabalaji, et al., 2012). Mukia maderaspatuna also shown zone of inhibition on Bacillus subtilis at the concentration of $100 \mu 1$. Since the inhibition zone is up to $14 \mathrm{~mm}$, it shows that B.subtilis is susceptible toward Mukia maderaspatuna. The Klebsiella pneumoniae is concluded to be resistant toward Mukia maderaspatuna since the maximum inhibition zone is only $12 \mathrm{~mm}$ even at the highest concentration.In a previous study, the ethanol extract of P.ambionicus showed a moderate antibacterial activity toward all the selected gram positive and gram negative bacteria (Uma Saraswati, et al.,2012). Similarly, acetone extracts of Mukia maderaspatuna also shows inhibitory effect on the S.aureus with maximum zone of inhibition $15 \mathrm{~mm}$ at the highest concentration of $200 \mu$ 1.In the present study the ethanolic extract of Aristolochia bracteolata has shown a less antibacterial activity against both Bacillus subtilis and Pseudomonas aeruginosa. This result is supported by the study conducted by (Chirag Modi et al., 2012). Where it was stated that all the tested gram negative bacteria including P.aeruginosa and Klebsiella pneumoniae showed zone of inhibition against acetone extract of Mukia maderaspatuna. 
Biochemical Test

\begin{tabular}{|c|c|c|c|c|c|c|}
\hline & & \multicolumn{5}{|c|}{ Organisms } \\
\hline S.No & Test & S.aureus & S.pyogenes & K.pneumoniae & B.subtilis & P.aeruginosa \\
\hline 1. & Gram strains & +ve & +ve & -ve & +ve & _ve \\
\hline 2. & Shape & Coccus & Coccus & Rod & Rod & Rod \\
\hline 3. & Motility & _ve & Non motile & Motile & +ve & Motile \\
\hline 4. & Indole & _ve & ve & $+v e$ & $+v e$ & -ve \\
\hline 5. & MR & _ve & +ve & _ve & _ve & $+\mathrm{ve}$ \\
\hline 6. & VP & _ve & +ve & $+v e$ & _ve & _ve \\
\hline 7. & Citrate & $+v e$ & +ve & _ve & +ve & $+\mathrm{ve}$ \\
\hline 8. & Urease & +ve & _ve & -ve & _ve & _ve \\
\hline 9. & Catalase & +ve & +ve & +ve & +ve & _ve \\
\hline 10. & Oxidase & _ve & _ve & _ve & _ve & $+\mathrm{ve}$ \\
\hline 11. & TSI & A/K/gas_ve & A/K/gas_ve & A/K/gas+ve & A/A/gas+ve & A/K/gas_ve \\
\hline
\end{tabular}

Some Selected Medicinal Plants used in the Antibacterial Activity

\begin{tabular}{|l|l|l|l|l|}
\hline $\begin{array}{l}\text { Vernacular } \\
\text { name }\end{array}$ & Scientific name & Pamily & Uses \\
\hline Adhatoda & Adhatoda vasica & Acanthaceae & Leaves & Whooping cough,chronic bronchitis \\
\hline Kayyanthara & Eclipta alba & Compositae & Leaves & $\begin{array}{l}\text { Rheumatic joint pain,digestion,enlarged } \\
\text { spleen }\end{array}$ \\
\hline Aduthinapalai & Aristolochia bracteolata & Aristolochiaaceae & Leaves & Puragative,anthelmintic \\
\hline Kandakathri & Solanum xanthocarpum & Solanaceae & Leaves & Gonorrhoea,cough,sore throat,rheumatism \\
\hline Omavalli & Plectranthus ambionicus & Lamiaceae & Leaves & Hiccough,epilepsy,chronic asthma \\
\hline Mosumosukkai & Mukia maderaspatuna & Curcurbitaceae & Leaves & Vertigo,biliousness,scabies \\
\hline Vilva maram & Aegle marmelos & Rutaceae & Leaves & Constipation,diarrhoea,dysentry \\
\hline Modakathan & $\begin{array}{l}\text { Cardiospermum } \\
\text { halicacabum }\end{array}$ & Sapindaceae & Leaves & Snake bites,itchy skin,ear ache \\
\hline Vilva ilai & Cordia myxa & Boraginaceae & Leaves & Ulcers and head ache \\
\hline $\begin{array}{l}\text { Thiruneetrupac } \\
\text { hilai }\end{array}$ & Ocimum basilicum & Labiatae & Leaves & Insect stings,snake bites and skin infections \\
\hline
\end{tabular}

Phytochemical Analysis

\begin{tabular}{|c|c|c|c|c|c|c|c|c|c|}
\hline \multirow[t]{2}{*}{ Plant name } & \multicolumn{3}{|c|}{ Saponins } & \multicolumn{3}{|c|}{ Tannins } & \multicolumn{3}{|c|}{ Terpenoids } \\
\hline & Acetone & Aqueous & Ethanol & Acetone & Aqueous & Ethanol & Acetone & Aqueous & Ethanol \\
\hline Aristolochia bracteolata & - & - & - & + & + & - & ++ & - & - \\
\hline Solanum xanthocarpum & - & - & - & - & ++ & - & & & \\
\hline Ocimum basilicum & - & - & - & + & ++ & - & & & \\
\hline Crdiospermum halicacabum & - & - & - & & & & & & \\
\hline Eclipta alba & - & - & - & & & & & & \\
\hline Cordia myxa & - & - & - & & & & ++ & + & - \\
\hline Aegle marmelos & - & - & - & & & & & & \\
\hline
\end{tabular}


Antibacterial Activity of Selected Herbal Plants

\begin{tabular}{|c|c|c|c|c|}
\hline \multirow[b]{2}{*}{ Plant name } & \multicolumn{4}{|c|}{ Inhibition of growth (Diameter in mm) } \\
\hline & & Acetone & Ethanol & Aqueous \\
\hline \multirow[t]{10}{*}{ Streptococcus pyogenes } & Aegle marmelos & - & - & $12.5 \mathrm{~mm}$ \\
\hline & Cordia myxa & $10 \mathrm{~mm}$ & $10 \mathrm{~mm}$ & $5 \mathrm{~mm}$ \\
\hline & Plectranthus ambionicus & $10 \mathrm{~mm}$ & $7 \mathrm{~mm}$ & $7 \mathrm{~mm}$ \\
\hline & Adhatoda vasica & - & - & - \\
\hline & Solanum xanthocarpum & $12.5 \mathrm{~mm}$ & $5 \mathrm{~mm}$ & $10 \mathrm{~mm}$ \\
\hline & Mukia maderaspatuna & $10 \mathrm{~mm}$ & $15 \mathrm{~mm}$ & - \\
\hline & Cardiospermum halicacabum & $7 \mathrm{~mm}$ & $6 \mathrm{~mm}$ & $12 \mathrm{~mm}$ \\
\hline & Eclipta alba & $10 \mathrm{~mm}$ & $6.3 \mathrm{~mm}$ & $10 \mathrm{~mm}$ \\
\hline & Ocimum basilicum & - & $15 \mathrm{~mm}$ & - \\
\hline & Aristolochia bracteolate & - & - & - \\
\hline \multirow[t]{10}{*}{ Pseudomonas aeruginosa } & Aegle marmelos & $7.5 \mathrm{~mm}$ & $6 \mathrm{~mm}$ & $5 \mathrm{~mm}$ \\
\hline & Cordio myxa & $5.5 \mathrm{~mm}$ & $9 \mathrm{~mm}$ & $5 \mathrm{~mm}$ \\
\hline & Plectranthus ambionicus & $7 \mathrm{~mm}$ & $5.5 \mathrm{~mm}$ & $6.5 \mathrm{~mm}$ \\
\hline & Adhatoda vasica & $6 \mathrm{~mm}$ & $17.5 \mathrm{~mm}$ & - \\
\hline & Solanum xanthocarpum & $5.5 \mathrm{~mm}$ & - & $6 \mathrm{~mm}$ \\
\hline & Mukia maderaspatuna & - & $7 \mathrm{~mm}$ & $7 \mathrm{~mm}$ \\
\hline & Cardiospermum halicacabum & $7.5 \mathrm{~mm}$ & $10 \mathrm{~mm}$ & $7.5 \mathrm{~mm}$ \\
\hline & Eclipta alba & $10 \mathrm{~mm}$ & $2.5 \mathrm{~mm}$ & $8 \mathrm{~mm}$ \\
\hline & Ocimum basilicum & $10.5 \mathrm{~mm}$ & $6.5 \mathrm{~mm}$ & - \\
\hline & Aristolochia bracteolate & - & $7.5 \mathrm{~mm}$ & $6 \mathrm{~mm}$ \\
\hline \multirow[t]{10}{*}{ Bacillus subtilis } & Aegle marmelos & - & $3.5 \mathrm{~mm}$ & $5 \mathrm{~mm}$ \\
\hline & Cordio myxa & - & $10 \mathrm{~mm}$ & - \\
\hline & Plectranthus ambionicus & - & $12 \mathrm{~mm}$ & - \\
\hline & Adhatoda vasica & $11 \mathrm{~mm}$ & - & - \\
\hline & Solanum xanthocarpum & $6 \mathrm{~mm}$ & $3 \mathrm{~mm}$ & - \\
\hline & Mukia maderaspatuna & - & $14 \mathrm{~mm}$ & - \\
\hline & Cardiospermum halicacabum & $6.5 \mathrm{~mm}$ & $7 \mathrm{~mm}$ & - \\
\hline & Eclipta alba & - & - & $3 \mathrm{~mm}$ \\
\hline & Ocimum basilicum & $9.5 \mathrm{~mm}$ & - & - \\
\hline & Aristolochia bracteolate & $4 \mathrm{~mm}$ & - & - \\
\hline \multirow[t]{9}{*}{ Klebsiella pneumoniae } & Aegle marmelos & $6 \mathrm{~mm}$ & $8 \mathrm{~mm}$ & $12 \mathrm{~mm}$ \\
\hline & Cordia myxa & $5 \mathrm{~mm}$ & $8 \mathrm{~mm}$ & $12 \mathrm{~mm}$ \\
\hline & Plectranthus ambionicus & $7 \mathrm{~mm}$ & $8 \mathrm{~mm}$ & - \\
\hline & Adhatoda vasica & $7 \mathrm{~mm}$ & $3 \mathrm{~mm}$ & $3.5 \mathrm{~mm}$ \\
\hline & Mukia maderaspatuna & $15 \mathrm{~mm}$ & $12 \mathrm{~mm}$ & - \\
\hline & Cardiospermum halicacabum & - & $5 \mathrm{~mm}$ & - \\
\hline & Eclipta alba & $10 \mathrm{~mm}$ & $10.5 \mathrm{~mm}$ & - \\
\hline & Ocimum basilicum & $6.5 \mathrm{~mm}$ & $8 \mathrm{~mm}$ & - \\
\hline & Aristolochia bracteolate & $10 \mathrm{~mm}$ & $5 \mathrm{~mm}$ & - \\
\hline \multirow[t]{10}{*}{ Staphylococcus aureus } & Aegle marmelos & $7 \mathrm{~mm}$ & $6.5 \mathrm{~mm}$ & $8 \mathrm{~mm}$ \\
\hline & Cordia myxa & $6.5 \mathrm{~mm}$ & $10 \mathrm{~mm}$ & $5 \mathrm{~mm}$ \\
\hline & Plectranthus ambionicus & $10 \mathrm{~mm}$ & $6 \mathrm{~mm}$ & $9 \mathrm{~mm}$ \\
\hline & Adhatoda vasica & $8 \mathrm{~mm}$ & $10 \mathrm{~mm}$ & - \\
\hline & Solanum xanthocarpum & $5 \mathrm{~mm}$ & $11 \mathrm{~mm}$ & $6 \mathrm{~mm}$ \\
\hline & Mukia maderaspatuna & $15 \mathrm{~mm}$ & $7 \mathrm{~mm}$ & - \\
\hline & Cardiospermum halicacabum & $12 \mathrm{~mm}$ & $10 \mathrm{~mm}$ & $7 \mathrm{~mm}$ \\
\hline & Eclipta alba & $6.3 \mathrm{~mm}$ & $8 \mathrm{~mm}$ & $2 \mathrm{~mm}$ \\
\hline & Ocimum basilicum & $10.5 \mathrm{~mm}$ & $12 \mathrm{~mm}$ & - \\
\hline & Aristolochia bracteolate & - & $5 \mathrm{~mm}$ & - \\
\hline
\end{tabular}


The presents study revealed that the acetone and ethanolic extract of both herbal plants has antibacterial activity against the common clinical pathogen of Pseudomonas aeruginosa, Klebsiella pneumoniae, Staphylococcus aureus and Streptococcus pyogenes. However both plants show higher antibacterial activity in Pseudomonas aeruginosa,Klebsiella pneumoniae and Bacillus subtilis. This proves that the leave extract of herbal plants higher inhibitory effect on gram positive bacteria (Staphylococcus aureus and Streptococcus pyogenes) compared togram negative bacteria (Pseudomonas aeruginosa and Klebsiella pneumoniae).This finding is supported by previous research studies where it was reported that the plant extract has higher potential to inhibit gram positive bacteria compared negative (Basari and Fan, 2005).Gram negative bacteria are more resistant to plants extract compared to gram positive bacteria similar to the study of (Archana et al., 2012). However, studies Adhatoda vasica has higher antibacterial activity toward gram positive and gram negative bacteria. According to Mihaela, gram positive bacteria have lack of additional permeability barrier compared to gram negative which makes it more susceptible toward the plant extracts (Mihaela Marilena, 2010).

\section{References}

Archana, S., Anju, M., Rishikesh, M. 2012. Antimicrobial activity of plant extracts of Ocimum tenuiflorum. Int. J. Pharm. Tech. Res., vol. 4(1): 176-180.

Azusu. 1986. Antioxidant and antibacterial study on Coleus aromaticus and Lawsonia inermis. Int. J. Pharm. Life Sci., vol. 3(9): 1958-1964.

Basari, D.F., Fan, S.H. 2005. The potential of aqueous and acetone extracts of galls quercus infectoria as antibacterial agents. Indian J. Pharmacol., vol. 35(1): 26-29.

Biswas, P.K. 2006. Encylopedia of Medicinal Plants.1st ed. Dominant publishers and Distributors, New Delhi, India, p.11-14.

Chirag Modi,Shailesh Mody, Hitesh Patel. 2012. Herbal antibacterial: a review. $J$. Intercultural Ethnopharmacol., vol. 1(1): 52-61.

Gil-Otaiza, R. 1997. Plantas usuales en la medicina popular,venezolana Edicion C.D.C.H.T-ULA (Merida), 52-54.

Krithiga, N., Jayachitra, N. 1958. Antioxidant and antibacterial study on Coleus aromaticus and Lawsonia inermis. Int. J. Pharmacy and Life Sci., vol. 3(9): 1958-1964.

Malcon, Sofowora. 1969. Antimicrobial screening of extracts of medicinal plant. Jr. Microbiotech., vol. 7: 556557.

Mihaela Marilena, L. 2010. Multiple Responses of gram-positive and gram negative bacteria to mixture of hydrocarbon. Brazilian J. Microbiol., vol. 4(1): 649-667.

Mukherjee, P.K. 2002. Quality control of Herbal Drugs.1st ed. Business Horizons, New Delhi, India, vol(2), p. 29-30.

Nadkarni, A.K. 1996. Indian materia medica (2nd edition). Mumbai: popular Prakashan, 371.

Naryanana, D.B.A., JKatayar, C.K. Brindhavanam, N.B. 1998. Original system, search, re-search. IDMA Bull., page 413-416.vol 29(17).

Opara, Ansa. 1993. Antimicrobial activity of plant Mukia maderaspatuna. Int. J. Pharm. Pharma. Sci., vol. 5: 200-202.

Prasannabalaji, N., Muralitharan, G., Sivanandan, R.N. 2012. Antibacterial activities of some Indian traditional plant extracts. Asian Pacific J. Trop. Dis., vol. 7(3): 291-295. 
Suri, R.K., Chuaudhari, D.C., Jaffer, R. 2003. Commercially important medicinal plants from forests. J. Eco. Bot. Phytochem., vol. 3(2): 129-140.

Uma, M., Saraswati, Kalaiselvi. 2012. Antimicrobial activity of Plectranthus ambionicus leaf extract against respiratory pathogens. J. Herbal Med. Toxicol., vol. 6(1): 187-193.

Warrier, Ps. 1994. Indian Medicinal plants,Arya vaida sala, kottakal, Hyderabad: Orient Longmann Limted, 315-7.

\section{How to cite this article:}

Akila, P., L. Prince, R. Bharathidasan and Krishnapriya, K. 2016. Antibacterial Activity of Herbal Plants. Int.J.Curr.Microbiol.App.Sci.5(4): 681-688.

doi: http://dx.doi.org/10.20546/ijcmas.2016.504.078 